\title{
Metabolic consequences after urinary diversion
}

\section{Raimund Stein* and Peter Rubenwolf}

Division of Pediatric Urology, Department of Urology, Mainz University Medical Center, Johannes Gutenberg University, Mainz, Germany

\section{Edited by:}

Barbara Magda Ludwikowski, Auf der Bult Children's Hospital, Germany

\section{Reviewed by:}

Ricardo González, Auf der Bult Children's Hospital, Germany

Hiep Thieu Nguyen, Boston Children's Hospital, USA

\section{*Correspondence:}

Raimund Stein, Division of Pediatric

Urology, Department of Urology,

Mainz University Medical Center,

Langenbeckstrasse 1, Mainz 55131,

Germany

e-mail: raimund.stein@

unimedizin-mainz.de
Metabolic disturbances are well-known, but sometimes neglected immediate consequences or late sequelae following urinary diversion (UD) using bowel segments. Whereas subclinical disturbances appear to be quite common, clinically relevant metabolic complications, however, are rare. Exclusion of bowel segments for UD results in loss of absorptive surface for its physiological function. Previous studies demonstrated that at least some of the absorptive and secreting properties of the bowel are preserved when exposed to urine. For each bowel segment typical consequences and complications have been reported. The use of ileal and/or colonic segments may result in hyperchloremic metabolic acidosis, which can be prevented if prophylactic treatment with alkali supplementation is started early. The resection of ileal segments may be responsible for malabsorption of vitamin $B_{12}$ and bile acids with subsequent neurological and hematological late sequelae as well as potential worsening of the patient's bowel habits. Hence, careful patient and procedure selection, meticulous long-term follow-up, and prophylactic treatment of subclinical acidosis is of paramount importance in the prevention of true metabolic complications.

Keywords: urinary diversion, metabolic complications, vitamin $\mathrm{B}_{12}$, acidosis, diarrhea

\section{METABOLIC ALTERATIONS AND COMPLICATIONS}

Whenever bowel segments are excluded from the gastrointestinal tract for urinary diversion (UD), the absorptive surface of the respective segment is irreversibly lost for physiological bowel function. Functional bowel loss affects the absorption of nutrients and water from small and large bowel (1-5). Some of the absorptive and secreting properties of bowel are preserved if exposed to urine, as clearly demonstrated by previous studies $(3,5)$. Typical metabolic consequences and complications have been reported for each bowel segment. They have been demonstrated to occur more frequently in patients having undergone continent UD due to the use of longer intestinal segments compared with shorter segments required for ileal and colonic conduits $(2,5,6)$. Metabolic disturbances involve mainly the electrolytes, loss of bile acids, and malabsorption of vitamin $B_{12}$, the extent of which depends on the length and type of bowel segment used, the duration of the storage interval, and the concentration of the urinary constituents the bowel is exposed to, the degree of atrophy of the bowel mucosa, and, importantly, the patient's renal and liver function. Further factors include patient age, status post irradiation or chemotherapy and primary or secondary diseases, which may promote or give rise to subsequent metabolic complications (3).

\section{ELECTROLYTES}

One of the most common metabolic consequences and complications are electrolyte imbalances. Whereas the majority of electrolytes freely traverse the intestinal segments across the apical surface of intestinal cells (transcellular movement), there is also some electrolyte movement between the cell borders (paracellular transport) (7).

\section{GASTRIC SEGMENTS}

Hypochloremic hypokalemic metabolic alkalosis may occur when gastric segments are used for UD; this has been reported to be life-threatening in some cases (8). The intestinal hormone gastrin seems to play a major role in this syndrome as with higher gastrin levels metabolic alkalosis becomes more severe (9).

\section{JEJUNUM}

The use of jejunum may entail hyponatremia, hypochloremia, hyperkalemia, azotemia, and acidosis paralleled by excessive loss of sodium chloride and by free water, which in turn can result in dehydration with subsequent hypovolemia and increased renin and aldosterone levels $(6,10)$. The more proximal and the longer the jejunal segment used, the more clinically relevant these disturbances may present as $(11,12)$.

\section{ILEAL AND COLONIC SEGMENTS}

Exclusion of ileal and colonic bowel segments may result in hyperchloremic metabolic acidosis. During the past 60 years, the underlying pathophysiological mechanisms have been the subject of intensive studies (7). Beside a complex interplay of various factors, ammonium ions $\left(\mathrm{NH}_{4}^{+}\right)$are believed to play a major role. When colonic or ileal segments are exposed to urine, ionized ammonium and chloride $\left(\mathrm{Cl}^{-}\right)$are reabsorbed by the mucosa (13-15). Mediated by a sodium-hydrogen antiport, ammonium absorption occurs in exchange of sodium $\left(\mathrm{Na}^{+}\right)(16)$. The exchange of ammonium $\left(\mathrm{NH}_{4}^{+}\right)$for a proton $(\mathrm{H}+)$ in turn is coupled with the exchange of bicarbonate for chloride $\left(\mathrm{Cl}^{-}\right)$(6). Furthermore, ionized ammonium may be also absorbed into the blood through potassium $\left(\mathrm{K}^{+}\right)$channels (17), resulting in potential bicarbonate and potassium losses.

\section{ACIDOSIS IN RELATION TO THE DIFFERENT TYPES OF URINARY DIVERSION}

In patients having undergone ileal conduit diversion, mild to moderate acidosis can be expected in up to $15 \%$. Up to $10 \%$ of patients will require antiacidotic treatment (18-20). In patients 
with a continent UD, the contact time of urine is markedly longer and the exposed surface of bowel mucosa is much larger. As a consequence, this can lead to a higher incidence of electrolyte disturbances. Therefore, metabolic acidosis has been reported in up to $50 \%$ of patients $(7,21)$. An elevated serum chloride concentration is associated with a decreased base excess $(2,7,22)$. Treatment of hyperchloremic acidosis consists of administration of alkalizing agents. Prophylactic alkali substitution should be commenced at a base excess below $-2.5 \mathrm{mmol} / \mathrm{L}$, with the aim of avoiding the long-term complications of clinically evident acidosis (23).

\section{BONE DENSITY}

Incorporation of ileal and/or colonic segments into the urinary tract can lead to chronic acidosis, which may play a major role in a decrease of bone mineral density following UD. The occurrence of rickets in children has been previously reported, but constitutes an extremely rare complication in practice. Similarly, osteomalacia and osteoporosis may develop in adults. However, the definition of osteoporosis in younger adults is not clearly established. At least three possible mechanisms underlying osteoporosis after UD have been described. Bone carbonate has the potential to buffer chronic acidosis in exchange for hydrogen ions with subsequent release of calcium into the circulation. Calcium is then cleared by the kidneys (24-26). Importantly, renal tubule calcium reabsorption is directly inhibited by sulfate $(7,27)$, with chronic acidosis being a cause for increased intestinal sulfate absorption. Furthermore, acidosis has been reported to activate osteoclasts resulting in further bone resorption (28). Finally, impaired intestinal absorption of both calcium and vitamin D may additionally develop in response to ileal resection (2).

With all these different pathophysiological pathways in mind, one could hypothesize that a substantial proportion of patients following UD using bowel segments will suffer from decreased bone mineralization. Indeed, there are some early reports of osteomalacia after ureterosigmoidostomy (29-31), ureterosigmoidostomy (32), Kock pouch (33), and segmental ileal ureteric replacement (34). Interestingly, remineralization of the bones was shown to be possible by correction of acidosis in two early reports $(35,36)$. Both animal and clinical studies have demonstrated, that the metabolic disturbances are not as severe as commonly assumed, and, even more importantly, that they could be prevented with the proviso that prophylactic treatment is initiated early $(1,26,37-$ 39). In clinical practice, mild chronic acidosis was shown to be preventable, if a base deficit of more than $-2.5 \mathrm{mmol} / \mathrm{L}$ was corrected early. In these patients, no signs of bone demineralization were observed (40). If osteomalacia occurs, correction of acidosis, dietary supplements with calcium, vitamin $\mathrm{D}$ and, in severe cases, bisphosphonates are recommended $(35,36,41,42)$.

\section{GROWTH RETARDATION}

In 1992, Mundy and Nurse as well as Wagstaff et al. found delayed linear growth in some children after UD $(43,44)$. The Baltimore group in the States observed decreased linear growth in patients with bladder exstrophy who had undergone intestinal augmentation, as opposed to those without augmentation (45). In a frequently cited long-term study of 93 patients with status post various treatment modalities for meningomyelocele (colonic conduit $n=2$, ileal conduit $n=28$, conservative treatment $n=63$ ) it was shown that those with UD had a decreased linear growth; the rate of complications following orthopedic surgery was $17 \%$ compared to $3 \%$ in the conservative group (46). Recurrent pyelonephritis occurred in $60 \%$ of the patients with a conduit as opposed to "only" $21 \%$ in the conservative group; likewise, deterioration of the upper urinary tract was observed in 57 and $8 \%$, respectively. All these factors may compromise renal function and thereby decrease the ability of the kidneys to counteract acidosis, which, as already stated above, has a negative impact on bone mineral density. Twenty percent of the patients with a conduit diversion had intermittent metabolic acidosis. At that time, the incidence of complications following orthopedic procedures in patients with meningomyelocele ranged between 16 and $29 \%(47,48)$.

It is of note, however, that conclusions of all of the above retrospective studies are limited by methodological shortcomings. For instance, it has been clearly demonstrated that a reduced bone mineral density is markedly more common in children with myelomeningocele than in others undergoing UD (49). In support of this, another recently published study provided compelling evidence that there is a significant correlation between low-bone density and wheelchair-dependence in children. Moreover, an association between reduced bone density and higher neurological deficit was suggested (50). Gerharz et al. emphasized, that it is worth to take a second look at the linear growth of patients who had undergone enterocystoplasty in childhood. In their study, the initial series by Wagstaff et al. were incorporated $(43,51)$. Eighty-five percent of patients remained on the same or reached a higher centile after surgery; only $15 \%$ were in a lower position, and clinically relevant growth retardation was recognized in only four patients. All these patients underwent a complete endocrinological evaluation demonstrating that enterocystoplasty was not the underlying cause of growth retardation in a single case. Therefore, it seems very unlikely that the post-operative loss of the changes in position on the growth curve is a consequence of the UD. Rather, it seems to be more likely a non-specific phenomenon that should be considered in any clinical population of similar size and age distribution after the same length of time (51).

\section{VITAMIN $B_{12}$}

Vitamin $\mathrm{B}_{12}$ (cobalamin) cannot be synthesized by mammalians and must be ingested from food. It plays an important role in DNA synthesis and neurological function. The acidic environment in the stomach facilitates the uncoupling of vitamin $B_{12}$ from food. The parietal cells in the stomach secrete intrinsic factor, which binds to vitamin $\mathrm{B}_{12}$ in the duodenum. In the ileum, the vitamin $\mathrm{B}_{12}$ intrinsic factor complex helps absorb vitamin $\mathrm{B}_{12}$ (52). Moreover, the so-called cubilin receptor, which is found in the entire ileum and not only in the terminal ileum, has also a physiological role in the absorption of vitamin $\mathrm{B}_{12}(53-55)$. Additionally, there is some evidence of the existence of an alternative system, which is obviously independent of the intrinsic factor or the terminal ileum and about $1 \%$ of orally administered vitamin $\mathrm{B}_{12}$ is absorbed by an additional, yet unknown, pathway $(52,56,57)$. Collectively, 
current knowledge suggests that the terminal ileum is not the only site of vitamin $\mathrm{B}_{12}$ absorption (56-61). A normal Western-style diet contains approximately $5-15 \mu$ g of vitamin $B_{12}$ per day; however, the daily requirement amounts to only $1-2 \mu \mathrm{g}$. Furthermore, the large hepatic vitamin $B_{12}$ depot in humans prevents symptoms of vitamin $\mathrm{B}_{12}$ deficiency over a period of $2-5$ years even in the presence of severe malabsorption (62). On the other hand, overt vitamin $B_{12}$ deficiency may result in megaloblastic macrocytic anemia, Hunter's glossitis, and funicular myelosis, an irreversible degeneration of spinal cord white matter. In most cases, however, vitamin $\mathrm{B}_{12}$ deficiency can remain completely asymptomatic (63, 64). In adults, resection of more than $60 \mathrm{~cm}$ of ileum increases the risk of development of a vitamin $B_{12}$ deficiency, as shown by some earlier studies (65-69). In children, impaired vitamin B12 absorption was demonstrated following resection of more than $45 \mathrm{~cm}$ of ileum demonstrated impaired vitamin $B_{12}$ absorption (70), whereas another study concluded that vitamin $\mathrm{B}_{12}$ absorption in children normalizes after ileal resection (71).

Other studies reported low vitamin $\mathrm{B}_{12}$ levels in adults in whom ileal segments had been used for UD. This was particularly evident if longer segments of ileum were used (22, 72-81). However, the length of excluded ileum is not the only contributing factor (82): radiation therapy $(83,84)$, patient age $(85-87)$, as well as administration of omeprazole (88) may all cause malabsorption of vitamin $\mathrm{B}_{12}$.

In children, no decrease in vitamin $\mathrm{B}_{12}$ levels was observed following bladder augmentation and substitution using ileal segments inmost cases after a follow-up period of up to 8 years (89). By contrast, Rosenbaum et al. demonstrated an increasing risk of vitamin $B_{12}$ deficiency after the seventh post-operative year when ileal segments had been used for bladder augmentation. In their study, 6 out of 29 patients had low vitamin $B_{12}$ levels (90). In a further study in which the ileocecal segment had been used, a slow decrease of serum vitamin $\mathrm{B}_{12}$ level was detected in more than $60 \%$ of patients; $8 \%$ underwent substitution after completion of a follow-up of 23 years (91).

In up to $35 \%$ of adult patients, substitution therapy is initiated following UD with ileal segments, such as ileal neobladder or ileocecal pouch $(22,74,76,77,79)$. It is of note, however, that there are only single case reports of a total of five patients with clinical symptoms (one with neurological symptoms) seemingly related to vitamin $\mathrm{B}_{12}$ deficiency $(72,76,79)$.

There are some controversies about the normal levels of vita$\min B_{12}$ and the impact of age on requirements. A serum vitamin $\mathrm{B}_{12}$ level $<100 \mathrm{ng} / \mathrm{L}$ is considered pathological, and some authors regard a range between 100 and $200 \mathrm{ng} / \mathrm{L}$ as borderline, whereas others recommend substitution of vitamin $B_{12}$ if the serum level is below $200 \mathrm{ng} / \mathrm{L}(52,64,85,92)$. It should be noted, that there is wide variation in vitamin $B_{12}$ serum levels both in adults and children. In children, however, supplementation should be considered if serum levels drop below $200 \mathrm{ng} / \mathrm{L}$, to be on the safe side $(90,91)$. Serum vitamin $B_{12}$ levels should be checked for annually starting at year five following UD.

With regard to the substitution of vitamin $B_{12}$ in patients with cobalamin deficiency, a randomized study provided evidence that oral therapy ( $2 \mathrm{mg}$ per day) is as effective as parenteral application (1 mg intramuscularly) (57).

\section{BOWEL DYSFUNCTION}

Chologenic diarrhea due to the loss of bile acids via the large bowel is one potential source of bowel dysfunction following UD using bowel segments. The pool of bile acids amount to around $2-4 \mathrm{~g}$ and circulates 5-10 times per day (referred to as "enterohepatic circulation") (93). In the ileum, active reabsorption of conjugated bile acids involves a $\mathrm{Na}^{+}$-coupled co-transport system (94), and most of the conjugated bile acids are absorbed in the ileum (95). However, alongside active transport, the enterohepatic circulation includes also passive absorption of deconjugated bile acids from the jejunum and ileum. Under the influence of bacterial enzymes in the colon, deconjugation, $7 \alpha$-dehydroxylation, and dehydrogenation of the conjugated bile acids occur (96) and only $0.2-0.4 \mathrm{~g}$ are lost through fecal excretion. This amount is normally synthesized by the liver. Therefore, the pool of bile acids remains by and large constant over time (97).

Resection of longer ileal segments may entail malabsorption of bile acids with subsequent excess transition of bile acids, water, and sodium into the colon. This can result in chologenic (bile acid) diarrhea (98). Multiple mechanisms of bile acid diarrhea are known $(96,99-102)$, but it remains still unclear which is the most important one (103). An increase of hepatic bile acid synthesis compensates for the loss. However, with increasing length of ileal resection, depletion of the bile acid pool can occur, resulting in malabsorption of fatty acids, which in turn can cause steatorrhea $(104,105)$. If the ileocecal valve is resected during UD, colonic organisms (e.g., Bacteroides ssp.) can enter the ileum, which is usually free of bacterial colonization. These microorganisms cleave bile acids from their conjungates. Free bile acids emulsify fat to a very low extent. As a consequence, micellar formation is reduced resulting in decreased fat absorption. This is a further cause of steatorrhea (106-108). Moreover, exclusion of the ileocecal valve decreases the intestinal transit time (0.8-2.5 h) (109) and thus, may increase stool frequency. Reconstruction of the ileocecal valve was previously recommended in patients with risk factors for developing post-operative diarrhea (110). However, in a long-term study using matched pairs, no difference was found between patients with and those without reconstruction of the ileocecal valve (111).

In the literature, only few reports have focused on bowel dysfunction after UD. In patients having undergone ileal or colonic conduit diversion, an increase of stool frequency was reported in $4-33 \%$, following bladder augmentation or substitution in $7-59 \%$, and after continent cutaneous diversion in 3-23\% (112-119). In this context, it is noteworthy, however, that stool incontinence has been reported as surprisingly common in epidemiological studies, with an estimated prevalence of up to $20 \%$ depending on age, gender, and population $(120,121)$.

In patients with chologenic diarrhea, the principle of treatment is a reduction of bile acids in the colon. It has been known for a long time that cholestyramine effectively binds bile acids and reduces stool frequency after ileal resection (122). Patients with a long-term use of this substance are at risk of interference of cholestyramine with the absorption of fat-soluble vitamins such as vit. A, D, and $\mathrm{K}(123,124)$. Therefore, vitamin levels should be checked. In patients with status post ileocecal pouch, no changes of the above vitamins were observed (125). Patients suffering from steatorrhea due to UD should be recommended a low fat diet. In 
patients with more severe bile acid malabsorption, cholylsarcosine (a bile acid analog) can be used for replacement (126) and substitution of fat-soluble vitamins may become necessary. Interestingly, there are only two reports on complications due to the lack of fat-soluble vitamins after bowel resection in adults (127, $128)$, whereas there are no reports thus far in patients after UD $(22,76)$.

\section{CONCLUSION}

Metabolic consequences and disturbances are quite common in patients after UD using intestinal segments. However, careful patient selection for various types of UD, prophylactic substitution therapy (alkali supplementation, vitamin $\mathrm{B}_{12}$ ), early intervention in case of overt clinical symptoms, and life-long follow up, can avert or successfully treat major clinical problems in the majority of cases.

\section{REFERENCES}

1. Stein R, Lotz J, Andreas J, Fisch M, Prellwitz W, Hohenfellner R, et al. Longterm metabolic effects in patients with urinary diversion. World J Urol (1998) 16(4):292-7. doi:10.1007/s003450050069

2. Mills RD, Studer UE. Metabolic consequences of continent urinary diversion. J Urol (1999) 161(4):1057-66. doi:10.1097/00005392-199904000-00002

3. McDougal WS. Use of intestinal segments and urinary diversion. 7th ed. In: Walsh PC, Retik AB, Vaughan ED, Wein AJ, editors. Campbell's Urology. Philadelphia: Saunders (1998). p. 3121-61.

4. Gilbert SM, Hensle TW. Metabolic consequences and long-term complications of enterocystoplasty in children: a review. J Urol (2005) 173(4):1080-6. doi:10.1097/01.ju.0000155248.57049.4e

5. Steiner MS, Morton RA. Nutritional and gastrointestinal complications of the use of bowel segments in the lower urinary tract. Urol Clin North Am (1991) 18(4):743-54.

6. Dahl DM, McDougal WS. Use of intestinal segments in urinary diversion. In: Wein AJ, Kavoussi LR, Novick AC, Partin AW, Peters CA, editors. CampbellWalsh Urology. Philadelphia: Saunders Elsevier (2007). p. 2534-78.

7. McDougal WS. Metabolic complications of urinary intestinal diversion. J Urol (1992) 147:1199-208.

8. Gosalbez R Jr, Woodard JR, Broecker BH, Warshaw B. Metabolic complications of the use of stomach for urinary reconstruction. J Urol (1993) 150(2 Pt 2):710-2.

9. Tanrikut C, McDougal WS. Acid-base and electrolyte disorders after urinary diversion. World J Urol (2004) 22(3):168-71. doi:10.1007/s00345-004-0430-z

10. Golimbu M, Morales P. Jejunal conduits: technique and complications. J Urol (1975) 113(6):787-95.

11. Klein EA, Montie JE, Montague DK, Kay R, Straffon RA. Jejunal conduit urinary diversion. J Urol (1986) 135(2):244-6.

12. Fontaine E, Barthelemy Y, Houlgatte A, Chartier E, Beurton D. Twenty-year experience with jejunal conduits. Urology (1997) 50(2):207-13. doi:10.1016/ S0090-4295(97)00210-0

13. Koch MO, Gurevitch E, Hill DE, McDougal WS. Urinary solute transport by intestinal segments: a comparative study of ileum and colon in rats. J Urol (1990) 143(6):1275-9.

14. Koch MO, McDougal WS, Reddy PK, Lange PH. Metabolic alterations following continent urinary diversion through colonic segments. J Urol (1991) 145(2):270-3.

15. Koch MO, McDougal WS, Thompson CO. Mechanisms of solute transport following urinary diversion through intestinal segments: an experimental study with rats. J Urol (1991) 146(5):1390-4.

16. Stampfer DS, McDougal WS. Inhibition of the sodium/hydrogen antiport by ammonium ion. J Urol (1997) 157(1):362-5. doi:10.1097/00005392199701000-00115

17. McDougal WS, Stampfer DS, Kirley S, Bennett PM, Lin CW. Intestinal ammonium transport by ammonium and hydrogen exchange. J Am Coll Surg (1995) 181(3):241-8.

18. Bowles WT, Tall BA. Urinary diversion in children. J Urol (1967) 98(5):597-605.
19. Schmidt JD, Hawtrey CE, Flocks RH, Culp DA. Complications, results and problems of ileal conduit diversions. J Urol (1973) 109(2):210-6.

20. Castro JE, Ram MD. Electrolyte imbalance following ileal urinary diversion. $\mathrm{Br}$ J Urol (1970) 42(1):29-32. doi:10.1111/j.1464-410X.1970.tb11903.x

21. Poulsen AL, Steven K. Acid-base metabolism after bladder substitution with the ileal urethral Kock reservoir. Br J Urol (1996) 78(1):47-53. doi:10.1046/j. 1464-410X.1996.00469.x

22. Pfitzenmaier J, Lotz J, Faldum A, Beringer M, Stein R, Thuroff JW. Metabolic evaluation of 94 patients 5 to 16 years after ileocecal pouch (Mainz pouch 1) continent urinary diversion. J Urol (2003) 170(5):1884-7. doi:10.1097/01.ju. 0000091900.57347.ee

23. Stein R, Wiesner C, Beetz R, Pfitzenmeier J, Schwarz M, Thuroff JW. Urinary diversion in children and adolescents with neurogenic bladder: the Mainz experience. Part II: continent cutaneous diversion using the Mainz pouch I. Pediatr Nephrol (2005) 20(7):926-31. doi:10.1007/s00467-005-1847-3

24. Bettice JA, Gamble JL Jr. Skeletal buffering of acute metabolic acidosis. Am J Physiol (1975) 229(6):1618-24.

25. Bushinsky DA, Krieger NS, Geisser DI, Grossman EB, Coe FL. Effects of pH on bone calcium and proton fluxes in vitro. Am J Physiol (1983) 245(2): F204-9.

26. McDougal WS, Koch MO, Shands C III, Price RR. Bony demineralization following urinary intestinal diversion. J Urol (1988) 140(4):853-5.

27. Koch MO, McDougal WS. The pathophysiology of hyperchloremic metabolic acidosis after urinary diversion through intestinal segments. Surgery (1985) 98(3):561-70.

28. Arnett TR, Dempster DW. Effect of $\mathrm{pH}$ on bone resorption by rat osteoclasts in vitro. Endocrinology (1986) 119(1):119-24. doi:10.1210/endo-119-1-119

29. Boyd JD. Chronic acidosis secondary to ureteral transplantation. Am JDis Child (1931) 42:366-71.

30. Harrison AR. Clinical and metabolic observations on osteomalacia following ureterosigmoidostomy. Br J Urol (1958) 30(4):455-62. doi:10.1111/j.1464410X.1958.tb03546.x

31. Specht EE. Rickets following ureterosigmoidostomy and chronic hyperchloremia. A case report. J Bone Joint Surg Am (1967) 49(7):1422-30.

32. Hossain M. The osteomalacia syndrome after colocystoplasty; a cure with sodium bicarbonate alone. Br J Urol (1970) 42(2):243-5. doi:10.1111/j.1464410X.1970.tb10029.x

33. Lundbeck F, Hasling C. Metabolic acidosis: an emerging problem in patients with intestinal segments as part of urinary diversion. A report of two cases. Scand J Urol Nephrol Suppl (1995) 172:37-41.

34. Salahudeen AK, Elliott RW, Ellis HA. Osteomalacia due to ileal replacement of ureters: report of 2 cases. J Urol (1984) 131(2):335-7.

35. Richards P, Chamberlain MJ, Wrong OM. Treatment of osteomalacia of renal tubular acidosis by sodium bicarbonate alone. Lancet (1972) 2(7785):994-7. doi:10.1016/S0140-6736(72)92405-1

36. Siklos P, Davie M, Jung RT, Chalmers TM. Osteomalacia in ureterosigmoidostomy: healing by correction of the acidosis. Br J Urol (1980) 52(1):61-2. doi:10.1111/j.1464-410X.1980.tb02921.x

37. Hochstetler JA, Flanigan MJ, Kreder KJ. Impaired bone growth after ileal augmentation cystoplasty. J Urol (1997) 157(5):1873-9. doi:10.1097/00005392199705000-00101

38. Tschopp AB, Lippuner K, Jaeger P, Merz VW, Danuser H, Studer UE. No evidence of osteopenia 5 to 8 years after ileal orthotopic bladder substitution. J Urol (1996) 155(1):71-5. doi:10.1097/00005392-199601000-00022

39. Poulsen AL, Overgaard K, Steven K. Bone metabolism following bladder substitution with the ileal urethral Kock reservoir. Br J Urol (1997) 79(3):339-47. doi:10.1046/j.1464-410X.1997.00376.x

40. Stein R, Fisch M, Andreas J, Bockisch A, Hohenfellner R, Thuroff JW. Wholebody potassium and bone mineral density up to 30 years after urinary diversion. Br J Urol (1998) 82(6):798-803. doi:10.1046/j.1464-410X.1998.00874.x

41. Perry W, Allen LN, Stamp TC, Walker PG. Vitamin D resistance in osteomalacia after ureterosigmoidostomy. N Engl J Med (1977) 297(20):1110-2. doi:10.1056/NEJM197711172972008

42. Lash RW, Nicholson JM, Velez L, Van Harrison R, McCort J. Diagnosis and management of osteoporosis. Prim Care (2009) 36(1):181-98. doi:10.1016/j. pop.2008.10.009

43. Wagstaff KE, Woodhouse CR, Duffy PG, Ransley PG. Delayed linear growth in children with enterocystoplasties. Br J Urol (1992) 69(3):314-7. doi:10.1111/j. 1464-410X.1992.tb15536.x 
44. Mundy AR, Nurse DE. Calcium balance, growth and skeletal mineralisation in patients with cystoplasties. Br J Urol (1992) 69(3):257-9. doi:10.1111/j.1464410X.1992.tb15524.x

45. Gros DA, Dodson JL, Lopatin UA, Gearhart JP, Silver RI, Docimo SG. Decreased linear growth associated with intestinal bladder augmentation in children with bladder exstrophy. J Urol (2000) 164(3 Pt 2):917-20. doi:10.1016/S00225347(05)67217-5

46. Koch MO, McDougal WS, Hall MC, Hill DE, Braren HV, Donofrio MN. Longterm metabolic effects of urinary diversion: a comparison of myelomeningocele patients managed by clean intermittent catheterization and urinary diversion. J Urol (1992) 147(5):1343-7.

47. Drummond DS, Moreau M, Cruess RL. Post-operative neuropathic fractures in patients with myelomeningocele. Dev Med Child Neurol (1981) 23(2):147-50. doi:10.1111/j.1469-8749.1981.tb02435.x

48. Reikeras O, Hellum C. Fractures in children with myelomeningocele. Arch Orthop Trauma Surg (1981) 98(1):25-8. doi:10.1007/BF00389706

49. Boylu U, Horasanli K, Tanriverdi O, Kendirci M, Gumus E, Miroglu C. Evaluation of bone mineral density after ileocystoplasty in children with and without myelomeningocele. Pediatr Surg Int (2006) 22(4):375-9. doi:10.1007/s00383006-1660-5

50. Apkon SD, Fenton L, Coll JR. Bone mineral density in children with myelomeningocele. Dev Med Child Neurol (2009) 51(1):63-7. doi:10.1111/j. 1469-8749.2008.03102.x

51. Gerharz EW, Preece M, Duffy PG, Ransley PG, Leaver R, Woodhouse CR. Enterocystoplasty in childhood: a second look at the effect on growth. BJU Int (2003) 91(1):79-83. doi:10.1046/j.1464-410X.2003.04012.x

52. Oh R, Brown DL. Vitamin B12 deficiency. Am Fam Physician (2003) 67(5):979-86.

53. Kozyraki R, Kristiansen M, Silahtaroglu A, Hansen C, Jacobsen C, Tommerup $\mathrm{N}$, et al. The human intrinsic factor-vitamin B12 receptor, cubilin: molecular characterization and chromosomal mapping of the gene to $10 \mathrm{p}$ within the autosomal recessive megaloblastic anemia (MGA1) region. Blood (1998) 91(10):3593-600.

54. Aminoff M, Carter JE, Chadwick RB, Johnson C, Grasbeck R, Abdelaal MA, et al. Mutations in CUBN, encoding the intrinsic factor-vitamin B12 receptor, cubilin, cause hereditary megaloblastic anaemia 1. Nat Genet (1999) 21(3):309-13. doi:10.1038/6831

55. Xu D, Fyfe JC. Cubilin expression and posttranslational modification in the canine gastrointestinal tract. Am J Physiol Gastrointest Liver Physiol (2000) 279(4):G748-56.

56. Elia M. Oral or parenteral therapy for B12 deficiency. Lancet (1998) 352(9142):1721-2. doi:10.1016/S0140-6736(05)79821-4

57. Kuzminski AM, Del Giacco EJ, Allen RH, Stabler SP, Lindenbaum J. Effective treatment of cobalamin deficiency with oral cobalamin. Blood (1998) 92(4):1191-8.

58. Hagedorn $\mathrm{CH}$, Alpers DH. Distribution of intrinsic factor-vitamin B12 receptors in human intestine. Gastroenterology (1977) 73(5):1019-22.

59. Baker SJ, Mackinnon NL, Vasudevia P. The site of absorption of orally administered vitamin B12 in dogs. Indian J Med Res (1958) 46(6):812-7.

60. Booth CC, Mollin DL. The site of absorption of vitamin B12 in man. Lancet (1959) 1(7062):18-21. doi:10.1016/S0140-6736(59)90979-1

61. Fleming WH, King ER. The site of absorption of orally administered Co60labelled vitamin B12 in dogs: the effect of dose. Gastroenterology (1962) 42:164-8.

62. Snow CF. Laboratory diagnosis of vitamin B12 and folate deficiency: a guide for the primary care physician. Arch Intern Med (1999) 159(12):1289-98. doi:10.1001/archinte.159.12.1289

63. Carethers M. Diagnosing vitamin B12 deficiency, a common geriatric disorder. Geriatrics (1988) 43(3):89-94.105-7, 111-2,

64. McRae T, Freedman M. Why vitamin B12 deficiency should be managed aggressively. Geriatrics (1989) 44:70-9.

65. Filipsson S, Hulten L, Lindstedt G. Malabsorption of fat and vitamin B12 before and after intestinal resection for Crohn's disease. Scand J Gastroenterol (1978) 13(5):529-36. doi:10.3109/00365527809181760

66. Papazian A, Minaire Y, Descos L, Andre C, Melange M, Vignal J. Relationships between the extent of ileal lesion of resection and vitamin B12, bile salt and fat absorption. Hepatogastroenterology (1981) 28(2):106-9.
67. Thompson WG, Wrathell E. The relation between ileal resection and vitamin B12 absorption. Can J Surg (1977) 20(5):461-4.

68. Lenz K. The effect of the site of lesion and extent of resection on duodenal bile acid concentration and vitamin B12 absorption in Crohn's disease. Scand J Gastroenterol (1975) 10(3):241-8.

69. Behrend C, Jeppesen PB, Mortensen PB. Vitamin B12 absorption after ileorectal anastomosis for Crohn's disease: effect of ileal resection and time span after surgery. Eur J Gastroenterol Hepatol (1995) 7(5):397-400.

70. Valman HB, Roberts PD. Vitamin B12 absorption after resection of ileum in childhood. Arch Dis Child (1974) 49(12):932-5. doi:10.1136/adc.49.3.171

71. Ooi BC, Barnes GL, Tauro GP. Normalization of vitamin B12 absorption after ileal resection in children. J Paediatr Child Health (1992) 28(2):168-71. doi:10.1111/j.1440-1754.1992.tb02635.x

72. Sagalowsky AI, Frenkel EP. Cobalamin profiles in patients after urinary diversion. J Urol (2002) 167(4):1696-700. doi:10.1097/00005392-20020400000026

73. Fujisawa M, Gotoh A, Nakamura I, Hara IS, Okada H, Yamanaka N, et al. Longterm assessment of serum vitamin $\mathrm{B}(12)$ concentrations in patients with various types of orthotopic intestinal neobladder. Urology (2000) 56(2):236-40. doi:10.1016/S0090-4295(00)00638-5

74. Olofsson G, Kilander A, Lindgren A, Ung KA, Jonsson O. Vitamin B12 metabolism after urinary diversion with a Kock ileal reservoir. Scand J Urol Nephrol (2001) 35(5):382-7. doi:10.1080/003655901753224440

75. Salomon L, Lugagne PM, Herve JM, Barre P, Lebret T, Botto H. No evidence of metabolic disorders 10 to 22 years after Camey type I ileal enterocystoplasty. J Urol (1997) 157(6):2104-6. doi:10.1016/S0022-5347(01)64685-8

76. Matsui U, Topoll B, Miller K, Hautmann RE. Metabolic long-term follow-up of the ileal neobladder. Eur Urol (1993) 24(2):197-200.

77. Akerlund S, Delin K, Kock NG, Lycke G, Philipson BM, Volkmann R. Renal function and upper urinary tract configuration following urinary diversion to a continent ileal reservoir (Kock pouch): a prospective 5 to 11-year followup after reservoir construction. J Urol (1989) 142(4):964-8.

78. Pannek J, Haupt G, Schulze H, Senge T. Influence of continent ileal urinary diversion on vitamin B12 absorption. J Urol (1996) 155(4):1206-8 doi:10.1016/S0022-5347(01)66217-7

79. Steiner MS, Morton RA, Marshall FF. Vitamin B12 deficiency in patients with ileocolic neobladders. J Urol (1993) 149(2):255-7.

80. Davidsson T, Lindergard B, Mansson W. Long-term metabolic and nutritional effects of urinary diversion. Urology (1995) 46(6):804-9. doi:10.1016/S00904295(99)80348-3

81. Narayan P, Broderick GA, Tanagho EA. Bladder substitution with ileocaecal (Mainz) pouch. Clinical performance over 2 years. Br J Urol (1991) 67(6):588-95. doi:10.1111/j.1464-410X.1991.tb15221.x

82. Ganesan T, Khadra MH, Wallis J, Neal DE. Vitamin B12 malabsorption following bladder reconstruction or diversion with bowel segments. ANZ J Surg (2002) 72(7):479-82. doi:10.1046/j.1445-2197.2002.02460.x

83. Kinn AC, Lantz B. Vitamin B12 deficiency after irradiation for bladder carcinoma. J Urol (1984) 131(5):888-90.

84. Jahnson S, Pedersen J. Cystectomy and urinary diversion during twenty years - complications and metabolic implications. Eur Urol (1993) 24(3): 343-9.

85. Bunting RW, Bitzer AM, Kenney RM, Ellman L. Prevalence of intrinsic factor antibodies and vitamin B12 malabsorption in older patients admitted to a rehabilitation hospital. J Am Geriatr Soc (1990) 38(7):743-7.

86. Scarlett JD, Read H, O'Dea K. Protein-bound cobalamin absorption declines in the elderly. Am J Hematol (1992) 39(2):79-83. doi:10.1002/ajh.2830390202

87. Yao Y, Yao SL, Yao SS, Yao G, Lou W. Prevalence of vitamin B12 deficiency among geriatric outpatients. J Fam Pract (1992) 35(5):524-8.

88. Marcuard SP, Albernaz L, Khazanie PG. Omeprazole therapy causes malabsorption of cyanocobalamin (vitamin B12). Ann Intern Med (1994) 120(3):211-5 doi:10.7326/0003-4819-120-3-199402010-00006

89. Canning DA, Perman JA, Jeffs RD, Gearhart JP. Nutritional consequences of bowel segments in the lower urinary tract. J Urol (1989) 142(2 Pt 2): 509-11.discussion 20-1,

90. Rosenbaum DH, Cain MP, Kaefer M, Meldrum KK, King SJ, Misseri R, et al. Ileal enterocystoplasty and B12 deficiency in pediatric patients. J Urol (2008) 179(4):1544-7. doi:10.1016/j.juro.2007.11.089 discussion 7-8, 
91. Stein R, Schröder A, Davis K, Thüroff JW. Vitamin $B_{12}$ deficiency in children after continent urinary diversion by Mainz pouch technique. Eur Urol (2010) 9(2):218. doi:10.1016/S1569-9056(10)60648-3

92. Chanarin I. The Megaloblastic Anemias. 1st ed. Oxford: Blackwell Scientific Publications (1979).

93. Everson GT, Lawson MJ, McKinley C, Showalter R, Kern F Jr. Gallbladder and small intestinal regulation of biliary lipid secretion during intraduodenal infusion of standard stimuli. J Clin Invest (1983) 71(3):596-603. doi:10.1172/JCI110805

94. Wong MH, Oelkers P, Craddock AL, Dawson PA. Expression cloning and characterization of the hamster ileal sodium-dependent bile acid transporter. J Biol Chem (1994) 269(2):1340-7.

95. Andersson H, Filipsson S, Hulten L. Determination of the faecal excretion of labelled bile salts after i.v. administration of 14C-cholic acid. An evaluation of the bile salt malabsorption before and after surgery in patients with Crohn's disease. Scand J Gastroenterol (1978) 13(2):249-55. doi:10.3109/ 00365527809181756

96. Martini GA, Menge H. Das kolon. 6 ed. In: Siegenthaler W editor. Klinische Pathophysiologie. Stuttgart: Georg Thieme Verlag (1987). p. 851-63.

97. Hofmann AF, Hoffman N. Measurement of bile and acid kinetics by isotope dilution in man. Gastroenterology (1974) 67(2):314-23.

98. Hofmann AF. Bile acid malabsorption caused by ileal resection. Arch Intern Med (1972) 130(4):597-605. doi:10.1001/archinte.1972.03650040121011

99. Quist RG, Ton-Nu HT, Lillienau J, Hofmann AF, Barrett KE. Activation of mast cells by bile acids. Gastroenterology (1991) 101(2):446-56

100. Karlstrom L, Cassuto J, Jodal M, Lundgren O. The importance of the enteric nervous system for the bile-salt-induced secretion in the small intestine of the rat. Scand J Gastroenterol (1983) 18(1):117-23. doi:10.3109/00365528309181570

101. Chadwick VS, Gaginella TS, Carlson GL, Debongnie JC, Phillips SF, Hofmann AF. Effect of molecular structure on bile acid-induced alterations in absorptive function, permeability, and morphology in the perfused rabbit colon. J Lab Clin Med (1979) 94(5):661-74.

102. Aldini R, Roda A, Festi D, Sama C, Mazzella G, Bazzoli F, et al. Bile acid malabsorption and bile acid diarrhea in intestinal resection. Dig Dis Sci (1982) 27(6):495-502. doi:10.1007/BF01296727

103. Potter GD. Bile acid diarrhea. Dig Dis (1998) 16(2):118-24. doi:10.1159/ 000016855

104. Hofmann AF, Poley JR. Role of bile acid malabsorption in pathogenesis of diarrhea and steatorrhea in patients with ileal resection. I. Response to cholestyramine or replacement of dietary long chain triglyceride by medium chain triglyceride. Gastroenterology (1972) 62(5):918-34.

105. Soong CS, Thompson JB, Poley JR, Hess DR. Hydroxy fatty acids in human diarrhea. Gastroenterology (1972) 63(5):748-57.

106. Kim YS, Spritz N, Blum M, Terz J, Sherlock P. The role of altered bile acid metabolism in the steatorrhea of experimental blind loop. J Clin Invest (1966) 45(6):956-62. doi:10.1172/JCI105411

107. Panish JF. Experimental blind loop steatorrhea. Gastroenterology (1963) 45:394-9.

108. Tilson MD. Pathophysiology and treatment of short bowel syndrome. Surg Clin North Am (1980) 60(5):1273-84.

109. Mojaverian P, Chan K, Desai A, John V. Gastrointestinal transit of a solid indigestible capsule as measured by radiotelemetry and dual gamma scintigraphy Pharm Res (1989) 6(8):719-24. doi:10.1023/A:1015998708560

110. Fisch M, Wammack R, Spies F, Muller SC, Mokthar A, Ghoneim M, et al. Ileocecal valve reconstruction during continent urinary diversion. J Urol (1994) 151(4):861-5.

111. Stein R, Schröder A, Schenk AC, Thüroff JW. Continent urinary diversion by ileocecal pouch - long-term outcome after reconstruction of the ileocecal valve in patients with impaired bowel function. J Urol (2006) 175(4):152.

112. Singh G, Thomas DG. Bowel problems after enterocystroplasty. Br J Urol (1997) 79:328-32. doi:10.1046/j.1464-410X.1997.03274.x

113. N’Dow J, Leung HY, Marshall C, Neal DE. Bowel dysfunction after bladder reconstruction. J Urol (1998) 159(5):1470-4. doi:10.1097/00005392199805000-00015 discussion 4-5
114. Roth S, Semjonow A, Waldner M, Hertle L. Risk of bowel dysfunction with diarrhea after continent urinary diversion with ileal and ileocecal segments. J Urol (1995) 154(5):1696-9. doi:10.1016/S0022-5347(01)66754-5

115. Henningsohn L, Wijkstrom H, Dickman PW, Bergmark K, Steineck G. Distressful symptoms after radical cystectomy with urinary diversion for urinary bladder cancer: a Swedish population-based study. Eur Urol (2001) 40(2):151-62. doi:10.1159/000049766

116. Awad SA, Al-Zahrani HM, Gajewski JB, Bourque-Kehoe AA. Long-term results and complications of augmentation ileocystoplasty for idiopathic urge incontinence in women. Br J Urol (1998) 81(4):569-73. doi:10.1046/j.1464-410x. 1998.00549.x

117. Stein R, Schenk A, Wiesner C, Thüroff JW. Bowel movements after urinary diversion - matched pairs of ileocecal pouch and ileal conduit. J Urol (2005) 173:486.

118. Webster C, Bukkapatnam R, Seigne JD, Pow-Sang J, Hoffman M, Helal M, et al. Continent colonic urinary reservoir (Florida pouch): long-term surgical complications (greater than 11 years). J Urol (2003) 169(1):174-6. doi:10.1097/00005392-200301000-00041

119. Somani BK, Kumar V, Wong S, Pickard R, Ramsay C, Nabi G, et al. Bowel dysfunction after transposition of intestinal segments into the urinary tract: 8-year prospective cohort study. J Urol (2007) 177(5):1793-8. doi:10.1016/j. juro.2007.01.038

120. Giebel GD, Lefering R, Troidl H, Blochl H. Prevalence of fecal incontinence: what can be expected? Int J Colorectal Dis (1998) 13(2):73-7. doi:10.1007/ s003840050138

121. Madoff RD, Parker SC, Varma MG, Lowry AC. Faecal incontinence in adults. Lancet (2004) 364(9434):621-32. doi:10.1016/S0140-6736(04)16856-6

122. Jacobsen O, Hojgaard L, Hylander Moller E, Wielandt TO, Thale M, Jarnum $\mathrm{S}$, et al. Effect of enterocoated cholestyramine on bowel habit after ileal resection: a double blind crossover study. Br Med J (Clin Res Ed) (1985) 290(6478):1315-8. doi:10.1136/bmj.290.6478.1315

123. Knodel LC, Talbert RL. Adverse effects of hypolipidaemic drugs. Med Toxicol (1987) 2(1):10-32. doi:10.1007/BF03259858

124. Vroonhof K, van Rijn HJ, van Hattum J. Vitamin K deficiency and bleeding after long-term use of cholestyramine. Neth J Med (2003) 61(1):19-21.

125. Stein R, Lotz J, Fisch M, Beetz R, Prellwitz W, Hohenfellner R. Vitamin metabolism in patients with a Mainz pouch I: long-term followup. J Urol (1997) 157(1):44-7. doi:10.1097/00005392-199701000-00013

126. Eusufzai S. Bile acid malabsorption: mechanisms and treatment. Dig Dis (1995) 13(5):312-21. doi:10.1159/000171511

127. Bertoni JM, Abraham FA, Falls HF, Itabashi HH. Small bowel resection with vitamin E deficiency and progressive spinocerebellar syndrome. Neurology (1984) 34:1046-52. doi:10.1212/WNL.34.8.1046

128. Graepler F, Gregor M, Riecken EO. Gangataxie bei Kurzdarmsyndrom: vitamin E-Mangelsyndrom. Med Klin (1992) 87:602-7.

Conflict of Interest Statement: The authors declare that the research was conducted in the absence of any commercial or financial relationships that could be construed as a potential conflict of interest.

Received: 26 January 2014; paper pending published: 12 February 2014; accepted: 22 February 2014; published online: 10 March 2014.

Citation: Stein $R$ and Rubenwolf $P$ (2014) Metabolic consequences after urinary diversion. Front. Pediatr. 2:15. doi: 10.3389/fped.2014.00015

This article was submitted to Pediatric Urology, a section of the journal Frontiers in Pediatrics.

Copyright (c) 2014 Stein and Rubenwolf. This is an open-access article distributed under the terms of the Creative Commons Attribution License (CC BY). The use, distribution or reproduction in other forums is permitted, provided the original author (s) or licensor are credited and that the original publication in this journal is cited, in accordance with accepted academic practice. No use, distribution or reproduction is permitted which does not comply with these terms. 